\title{
Interrogatives in English and Serbian Academic Discourse - A Contrastive Pragmatic Approach
}

\begin{abstract}
The paper presents the results of a corpus-based contrastive study of interrogatives in written academic discourse in English and Serbian. Three corpora were analyzed (articles written by English and Serbian authors in their mother tongues, and by Serbian writers in English) in order to establish the distribution and functions of interrogatives, with the special emphasis on possible transferring of writing habits from the authors' native written culture to the AngloAmerican one. The analyzed academic articles come from various social and hard sciences, in order both to establish cross-disciplinary variations and, more importantly, to depict some culture-based preferences in the use of interrogatives. Being rarely used as the request for information in academic articles, the interrogatives are viewed as indirect speech acts performing various interpersonal functions, such as drawing the readers' attention to a specific idea or result, announcing or giving comments on the proposition material, or establishing contact with the reader.
\end{abstract}

\section{Key words}

Contrastive study; interrogatives; written academic discourse; writing habits; indirect speech acts; culture-based preferences

\section{Introduction}

The focus of interest in the study of both theoretical and practical aspects of academic discourse has for some time been shifted from the issues of content and its logical organization to more interpersonally-oriented issues of writer and reader involvement. In literature, this is known as metadiscourse and its various elements and features have been analyzed in different types of academic discourse, both in individual languages 
and cross-linguistically (Williams, 1985, Vande Kopple 1981, 1985, Crismore and Farnswarth 1990, Nash 1992, Mauranen 1993, Hyland 2005a, etc.).

The aim of this paper is to examine one particular metadiscourse feature - interrogatives in academic discourse, by comparing and contrasting two languages, English and Serbian. Although questions themselves have received considerable attention in the study of academic writing, both in their own right (Webber 1994, Hyland 2002a) and as one of the so-called dialogic features, engagement in particular (Frank 1990, Hyland 2001, 2004, 2005b), or as one type of directives (Hyland 2002b, 2008), there have been relatively few studies of interrogatives that included languages other than English or comparative studies. Most importantly, there have been no studies so far of interrogatives in Serbian or English written by Serbian academic writers.

The purpose of this study is therefore manifold: a) to enrich the current findings on questions in academic writing with a more pragmatic theoretical point of view, and, hopefully, provide some new data, and b) to examine Serbian academic discourse practice in the use of interrogatives, both in the Serbian and English language. The particular focus of this paper is to point to the differences and similarities between the use of questions in the examined corpora and draw conclusions that could contribute not only to a better understanding of how Serbian academics write in English and to the improvement of academic writing instruction for Serbian learners, but also to the understanding of this phenomenon in general.

\subsection{Interrogatives in academic writing}

Interrogatives in academic writing can be thought of as a relatively marginal phenomenon due to their very low frequency. In large-scale studies done by Ken Hyland $(2002 b, 2004,2008)$, which included huge and diverse corpora (1.5 million words), it was established that questions make up from only 1.4 (in philosophy) to as little as 0.1 (in mechanical engineering) items per 1,000 words. However, due to their prominence, the way they 'stand out' in academic writing normally characterized by declarative sentences and statements, and due to their specific discourse functions, which contribute to the dialogic nature of academic writing, interrogatives have proved to be worth studying.

\subsection{Methodology}

In this study we have analyzed three types of corpora, each with several subtypes. The three corpora are:

(1) English academic articles written by native speakers of English (labelled 'ET corpus'),

(2) Serbian academic articles written by native speakers of Serbian (labelled 'ST corpus'), and 
(3) Academic articles in English written by native speakers of Serbian (labelled 'ETS corpus').

All three corpora contain the same number of articles - 36 per corpus, 108 total. Each corpus contains articles from both social sciences (sociology, philosophy and psychology, 6 articles from each discipline) and hard sciences (chemistry, geology and ecology, 6 articles from each discipline). The number of words per article in social sciences is approximately 7,000 words per article, ranging from approx. 122,000 to 126,000 words per corpus. The approximate number of words per article in hard sciences is approximately 5,600 words per article, approximately 100,800 words per corpus.

After the interrogatives have been identified and statistically processed for each corpus type and subtype, they were classified according to the syntactic type. In the next stage of the analysis we tried to identify and establish the discourse functions of these interrogatives and establish if there is some correlation between the syntactic type, the position of the interrogative in the text and the discourse function. In the final stage of the analysis, we compared all the data (statistic, syntactic, discourse) from all three corpora, to reach some conclusions.

\subsection{Theory}

1.4.1. The theoretical framework for our analysis of interrogatives in academic writing has been primarily provided by two theoretical constructs - the theory of metadiscourse and the theory of speech acts.

Metadiscourse is defined as "an author's overt or nonovert presence in the discourse in order to direct rather than to inform readers: the linguistic material given to readers so they will understand what is said and what is meant in the primary discourse" (Crismore and Farnswarth 1990: 119). This means that academic discourse, as many other discourses, "has at least two levels. At one level we supply information about the subject-matter of our text. At this level we expand the propositional content. At the other level, the level of metadiscourse, we do not add propositional material but help our readers organize, classify, interpret, evaluate, and react to such material. Metadiscourse, therefore, is "discourse about discourse or communication about communication" (Vande Kopple 1980: 83). Thus, academic writers select and use the linguistic features which will, according to their opinion, facilitate their communication with the anticipated audience, not only by means of guiding the readers through the text, but by demonstrating the writer's perspective and his/her attitude both toward the content and the target readership.

The linguistic features traditionally placed under the label of 'metadiscourse' are often divided into two groups which comprise 'textual and interpersonal metadiscourse' (Vande Kopple 1980, Crismore and Farnswarth 1990). However, this is not always a clear-cut distinction, which is especially significant when trying to classify interrogatives used in academic discourse. As demonstrated in section 2.2. of this paper, interrogatives may be used for fulfilling text organizing 
purposes, as for example, to announce a new portion of the propositional material, and also for expressing interpersonal purposes, as when used to invite the reader to agree with the writer's ideas conveyed through the text.

Besides this specific issue concerning the use of interrogatives in academic discourse, of equal importance is another one, which deals with the use of metadiscourse as a culture-based phenomenon. Various studies on metadiscourse (Clyne 1987, Clyne 1988, Crismore at al. 1993, Mauranen 1993, Connor 1996, Blagojević 2004, Blagojević 2007, Čmejrková 1996, 2007, Chamonikolasová 2005, DontchevaNavratilova 2008, Mur-Dueñas, 2010, Povolná 2010, Stašková 2004, etc.) have proven that metadiscourse is differently displayed in academic discourses written by writers of different cultural backgrounds, which means that the use of metadiscoursal elements in academic articles does not depend on the writer's personal choice and his/her individual style only, but that this choice is conditioned by the writing habits favoured in the writing culture to which the academic writer belongs.

1.4.2. The other important theoretical construct in our study is the pragmatic theory of speech acts. Formulated in the works of J. Austin (1962) and J. Searle (1969), and later expanded and modified in various ways, here it will be briefly explained based on Levinson (1983: 226-283), Sadock $(1995,2004)$ and Bach (1998). Most generally, this theory analyzes the role of utterances in relation to the behaviour of the speaker and the listener in interpersonal communication. The utterance is viewed as a complex phenomenon consisting of locution (the act of uttering a proposition), illocution (what the speaker intends/achieves by uttering the proposition) and perlocution (the effect the utterance has on the hearer). The utterance consists of a proposition (p) and formal characteristics that determine a particular illocutionary force, called the illocutionary force indicating device (F), so the complete speech act can be formally represented as $\mathrm{F}(\mathrm{p})$.

Canonically, there is a correspondence between linguistic form and illocutionary force. Such speech acts are called direct. Thus, for instance, declarative mood is reserved for expressing assertions, and the speaker's goal is the transfer of knowledge and beliefs, whereas interrogative mood is used for expressing questions, and the speaker's goal is to know the answer. On the other hand, sometimes the mood and the illocutionary force do not coincide, and such cases of mis-alignment are called indirect speech acts, where one illocutionary act is performed indirectly via another.

In this paper we view interrogatives in academic writing as a specific type of complex indirect speech acts. Trying to formalize them pragmatically, we will follow the questions and elements postulated by Sadock (1995: 400-402), and modify them to refer to interrogatives. The questions are:

(a) What representation of the world is made? In other words, what kind of proposition is expressed by the interrogative speech act?

(b) What conventional effect is achieved by the interrogative speech act?

(c) What attitude is expressed? 
If we apply this to interrogatives in general, we can answer the following:

(a) The expressed proposition is: there is some unknown information for which the speaker assumes that the hearer knows.

(b) The conventional effect is that the hearer is invited to supply the unknown information.

(c) The expressed attitude is the speaker's desire to obtain the answer, that is, the unknown information from the hearer.

Now, if we consider interrogatives in academic writing along these lines, we can see that they do not fit into any of these formalized questions and answers. Thus

(a) the information sought by the question is not unknown to the speaker. (More precisely, since we are dealing with written communication, instead of the terms speaker and hearer, from now on we will be using writer and reader.) Besides, the writer does not necessarily assume that the reader knows it. More likely, it is quite the opposite, since the writer assumes that the reader does not know or is not aware of the information sought by a particular interrogative in an academic text.

(b) The conventional effect is that the reader is not expected to provide the answer, that is, to supply the information. What is more, since this is written, nonpersonalized communication, the reader can hardly be expected to be able to respond directly and immediately.

(c) The expressed attitude of the writer is far from straightforward and unified, but definitely it is not to obtain the answer from the reader, who should supply the unknown information.

Therefore, we can conclude that interrogatives in academic writing should definitely be treated as indirect speech acts. Moreover, the most challenging task would be to recognize the last element, that is, to recognize the expressed attitude. This can be done only by taking into account the context in which the interrogative is used.

As we can see, the theory of indirect speech acts can provide a richer and more coherent framework than a simple treatment of interrogatives in academic writing as simple rhetorical questions, a kind of a stylistic device, almost an ornament.

\section{Analyses}

\subsection{Syntactic analysis}

The previous studies of questions in academic writing included only direct questions. In our analysis we have also included the so-called indirect and reported 
questions (labelled 'embedded questions' and 'subordinate interrogatives' in Huddleston and Pullum 2002), because they too can be considered interrogatives. Moreover, due to the specific speech act, performative verbs and devices that introduce subordinate interrogatives, it is easy to identify their discourse function, although they are not as conspicuous in the text as direct questions.

According to their form, the following types of interrogatives have been identified in each of the three corpora:

\section{Direct questions starting with a question word}

Since in English these questions are commonly referred to as 'wh-questions', we will use that term, both for English and Serbian.

(1a) What are the historic preconditions for this contemporary 'knowledge'? (ET1/s, p. 71)

(1b) Zašto ranjenici pokazuju povišenu zaštitu a sniženu orijentaciju u odnosu na svoju populaciju, što je dijametralno suprotno karakteristikama osoba sa borbenim iskustvom? (ST14/s, p. 430)

(1c) What did the research of social change and social character in Serbia of the '90s reveal in this respect? (ETS18/s, p. 449)

\section{Direct yes-no questions}

These questions are formed by subject-auxiliary inversion in English. The auxiliaries can be both primary and modal auxiliaries. In Serbian such questions start with one of the interrogative markers ( $d a l i$, je li or zar), and can be either with or without subject-verb inversion.

$\left(2 a_{1}\right)$ Are these interactions similar or different in the molecular sense? (ET5/h, p. 605)

$\left(2 a_{2}\right)$ Can the gendering of the categories of immanence and transcendence survive the disruption of the dichotomy between them? (ET6/s, p. 9)

(2b) Da li su, zaista, geopolitički razlozi toliko značajni, gotovo fatalni za naše nacionalno biće i istporijsku sudbinu u kosovskoj epopeji, koja traje od kraja 14. veka pa sve do danas? (ST4/s, pp. 9-10)

(2c) Is it necessary that a person respect him/herself? (ETS16/s, p. 25)

\section{Negative interrogatives of yes-no type}

(3a) For example, are there not portions of some of the reading lesson books which would have no place there, if the books were compiled exclusively 
for the formation and the information of the female mind, - while there would have been no need for any corresponding omissions, if the books were exclusively for male? (ET1/s, p. 79)

(3b) Nisu li tekovine pomenutih revolucija delovanjem aktera agresije kao katastrofalnih ljudi naprosto zbrisane? (ST5/s, p. 64)

(3c) Wouldn't it be possible to more reliably monitor the trend of inequalities in the economic positions of households on the basis of the composite index of economic status. (ETS9/s, p. 141)

In English it is possible to have two versions of a yes-no negative question - one where the negative particle is contracted and directly attached to the inverted auxiliary (as in 3c) or, where the negative is not contracted, so only the auxiliary is inverted while the negative particle remains in the canonical declarative position after the subject (example 3a). The version with the non-contracted negative particle, characteristic for spoken discourse, is felt as more emphatic and formal.

It is theoretically possible to have a $w h$ - negative interrogative. For example: Why isn't it possible to find such questions? However, only one such example was found in the corpus, with the non-contracted negative particle and it is given as (14) below.

\section{Indirect or reported (embedded) questions:}

Syntactically, indirect and reported questions are subordinate nominal clauses of wh- or if/whether type, preceded by clauses containing an illocutionary force marking device, such as a verb (ask, wonder...) or a noun (question, answer...).

(4a) One can only wonder how accessible self-information would become if egocentric comparison were a day-to-day strategy in social judgment. (ET11/s, p. 288)

(4b) Pitanje je koliko ljudi u haotičnim vremenima uviđaju neku vezu između stavova prema aktuelnom (često sasvim novim) pojavama i svim temeljnim vrednostima. (ST16/s, p. 157)

(4c) We wondered whether these differences are presented only in students who are religious as opposed to those who are from the same school but not religious. (ETS 16/s, p. 20)

\section{Other forms of interrogatives in academic writing:}

Theoretically, it is also possible to have other forms of interrogatives, such as tag questions, or alternative questions, or echo questions, or statements followed by question marks, functioning as questions (as illustrated in many grammars of English, e.g. Biber et al. 1999, Carter and McCarthy 2006). We have not found any of them in any of the corpora, so we will not provide corpus illustrations. 
However, we should note that in the Serbian corpus we found two examples of a noun phrase (example 5) and an adjective (example 6) followed by a question mark, clearly indicating the author's rhetorical intention. Example (5), the NP followed by the question mark, is actually the title of the article.

(5) Kriza (države) blagostanja? (ST17/s, p. 217)

(6) Odnosno ova druga (umerenija?) grupa teoretičara tvrdila je „,da je čitav arsenal državnih prinudnih mera u oblasti socijalnog osiguranja, zdravstva, obrazovanja, stanovanja itd. zamišljen i uveden u neko drugo vreme, kada je vredelo rešavati probleme koji su definitivno izgubili na aktuelnosti (poput bede, siromaštva, nezaposlenosti, ekonomske stagnacije i slično. (ST17/s, p. 217)

As for alternative questions, although in the corpus we have not found an example where two complete interrogative forms are coordinated by means of or, we found a few examples with alternative coordination of smaller units, for example adjectives, as can be seen in (11c) below.

Regarding the distribution of various syntactic types in the corpus, it should be stressed that, although we did not count the tokens of each syntactic type in each of the subcorpora, it can be noted that the subordinate interrogatives, both as indirect or reported questions, seem to be the most frequent type.

\subsection{Pragmatic-functional analysis}

The literature dealing with questions in academic writing and their functions (both practical guides to academic writing style, Study skills: Warwick web site, Hyper grammar web site, Mwansoko 2003), reference books and research articles on metadiscourse (Webber 1994, Chang and Swales 1999, Hyland 2001, Hyland 2002a, Ädel 2006) mention a variety of discourse functions, which sometimes overlap, although they are usually defined and specified in somewhat different terms.

However, what is common is that these questions are considered interactive features, which help establish a closer contact between the writer and the readers. Hyland (2004: 5-23) uses the term 'dialogic involvement', or, more specifically, 'engagement features' (which, together with questions, include pronouns, directives, obligation modals, envoking shared knowledge, and asides to the reader).

In our analysis it proved useful to examine the functions of interrogatives in relation both to their form and to their position in the article.

2.2.1. As for the position of the interrogative in the article, it can be viewed as:

(a) a specific rhetoric part of the article (Introduction, Method, Results, Discussion, Conclusion), and

(b) a part of a paragraph (the very beginning, middle, or the end) in which an interrogative is placed. 
The position of interrogatives in an academic article's rhetoric part usually coincides with their discourse functions. For instance, one of the noted functions (see section 2.2.2.) is to announce or present the writer's purpose. Depending on the part of the article, thus, the interrogative in the article's Introduction, always has the function to announce the aim of the paper (examples $8 \mathrm{a}-8 \mathrm{c}$ below), while in the Discussion, it can announce the further survey of the problem under consideration (as illustrated by examples $9 \mathrm{a}-9 \mathrm{c}$ below), or draw the reader's attention to a specific point (examples 10a-10c below). On the other hand, in this section it can also be used to invite the reader to discuss the problem jointly (examples $11 \mathrm{a}-\mathrm{c}$ and $12 \mathrm{a}-\mathrm{c}$ below). Interrogatives can also be found in the Conclusion, usually to start the concluding remarks with, and even sometimes at the very end of an article (as illustrated by example 14 below).

Regarding the position of an interrogative within a paragraph, our findings indicate that it is related to the very nature of one of these interrogatives, that is, to the fact that they are rhetorical and do not require the answer from the reader. In each of our corpora, it seems that there is a tendency that questions placed at the very beginning of a paragraph, or in its middle part, are most often followed by an immediate answer (in the sentence that follows, as in example 7a). Huddleston and Pullum (2002: 867) note such an example among those which are not inquiries and label the type 'expository question'. On the other hand, when a question is placed at the very end of the paragraph, it is usually followed by a larger portion of explications, thus functioning as the announcer of the part of the article which follows. This was the case in $7 \mathrm{~b}$ and $7 \mathrm{c}$, where we have to omit the whole explanation because of its length.

(7a) How can such an error be endemic in discourse? The answer lies in the significance of the principal site in which cultural practices are held to be linked to structural position - that is, in the meaning of the family in contemporary discourse on truancy. (ET1/s, p. 69)

(7b) Na koji bi to onda kognitivni domen ovakve razlike u reakcijama mogle da ukazuju? (ST6/s, p. 145)

(7c) What are the historic preconditions for this contemporary 'knowledge'? (ETS1/s, p. 71)

2.2.2. Although we cannot claim that there is any kind of direct correspondence between the form of an interrogative and its discourse function in an academic article, it is nevertheless possible to view the function as related to the combination of positional, syntactic and semantic and pragmatic factors. Moreover, the discourse functions clearly reflect a complexity of attitudes the writer expresses in performing this indirect speech act.

One of the most obvious functions of the interrogatives is to present the writer's purpose, to guide the reader through the text. In a way, this function can be 
considered as belonging both to the textual and the interpersonal metadiscourse. As stated above, depending on the specific part of the article, the author can thus announce the aim of the paper, or the further consideration of the problem, or the overview and the concluding remarks. Sometimes, the writers very explicitly indicate their questions, by introducing them with phrases containing words such as ask, question, answer, stating their purpose and inviting the reader to join it. Here are some illustrations of how the writer announces the aim of the paper, using either direct (examples $8 \mathrm{a}$ and $8 \mathrm{c}$ ) or embedded (example 8b) questions.

(8a) Before we start, you may be tempted to ask, "well, what of it? Is it really necessary for us to bother about complicated questions of science and philosophy?" (ET16/s, p. 3)

(8b) Postavlja se pitanje za koje se identitete ljudi vezuju u ovom istorijskom trenutku. (ST19/s, p. 125)

(8c) The questions we try to answer are: What is self-image? What are the elements of self-image that are present in all young people regardless of their religious affiliation? (ETS16/s, p. 20)

The following examples illustrate how the writers announce a new portion in their proposition material, that is, announce the further survey or discussion of the problem. These examples come from the middle parts of the articles.

(9a) What are the two processes, now, into which the room-experience simultaneously enters in this way? (ET17/h, p. 9)

(9b) Šta je alternativa modernizaciji? (ST12/s, p. 325)

(9c) What significance does the above mentioned have for the case of Serbia? (ETS17/s, p. 45)

Another function, most often found in the middle sections of the articles, which, as the two previous ones, is of both the textual and interpersonal nature, is to draw the reader's attention to a specific point.

(10a) But what model of the social are we subscribing to when access to full humanity is indicated by the confirmation of one's purchasing power? (ET13/s, p. 146)

(10b) Kako to izgleda u našem primeru? (ST14/s, p. 433)

(10c) To what extent do the news redesign the actual events, designing thereby the minds of the viewers? (ETS1/s, p. 590) 
The remaining functions that we identified are even more directly oriented towards the reader, making him/her the direct participant in the argumentation process. The author tries to involve the reader in the discussion by asking direct questions, both of wh- and yes/no type.

(11a) Does it really mean that $D$. immigrants males are indiscriminate in respect to body size of females? (ET4/h, p. 23)

(11b) Zašto ranjenici pokazuju povišenu zaštitu, a sniženu orijentaciju u odnosu na svoju populaciju, što je dijametralno suprotno karakteristikama osoba sa borbenim iskustvom? (ST14/s, p. 430)

(11c) Are these interactions similar or different in the molecular sense? (ET5/h, p. 605)

Inviting the reader to discuss the problem together is most straightforward when done by direct question and using the pronoun we, the so-called 'inclusive we', which includes both the writer and the reader, and in a way creates a bond between them. We have indicated such uses of we (or the verb form with $1^{\text {st }}$ person plural suffix in Serbian) by italics in the examples below.

(12a) But what model of the social are we subscribing to when access to full humanity is indicated by the confirmation of one's purchasing power? (ET13/s, p. 146)

(12b) Kakve zaključke možemo izvesti na osnovu analiziranih rezultata istraživanja religioznosti u Jugoslaviji i kakva je budućnost religijskocrkvenog kompleksa na našim viševerskim prostorima? (ST2/s, p. 90)

(12c) To what extent can we explain this question? (ETS16/s, p. 34)

The writer can use interrogatives in order to invite the reader to agree with, or to approve what has been said. In this way, the writer makes a comment on the already presented content and reinforces the validity of his/her ideas.

(13a) One can only wonder how accessible self-information would become if egocentric comparison were a day-to-day strategy in social judgment. If self-information were that frequently primed, how could it not help but influence people's judgments of others? (ET11/s, p. 228)

(13b) Nije li to nelogično i protivurečno srži PTSP-a? (ST14/s, p. 432)

(13c) Would here be reasonable to conclude that this answer is indication of the system where army service is obligatory and 21 and 30 is the age when young men in Serbia get engaged with the army? (ETS1/s, p. 50) 
If used in the closing remarks or in the concluding section, these interrogatives can be viewed as a kind of the writer's rhetoric strategy to persuade the readers in the validity of the conclusion which he/she presents to them, or better to say, to help the readers cast away any doubt concerning this validity.

(14a) If that effort is not disproportionate opposition of the intellectuals, then what else could it be? (ET14/s, p. 136)

(14b) Ako je liberalni pristup obrazovanju bio pogodna osnova za neke od pomenutih društvenih pojava, zar se i sociolozi ne bi morali osećati bar unekoliko odgovornim za postojeće stanje? (ST8/s, p. 87)

(14c) Has not the research shown that the informal register reflects the higher rate of the shift towards the egalitarian values? (ETS11/s, p. 267)

We have noted a correlation between the interrogative form and the function of reinforcing the validity of the arguments by inviting the reader to agree. The negative interrogatives, of both yes/no and $w h$-type are only exclusively used for this function. Huddleston and Pullum (2002: 867) label them 'biased', because the speaker/ writer seems to favour one particular answer and expects the listener/reader to confirm that it is so. Our examples belong to the special subtype of epistemic bias.

Some studies (Heritage 2002, Han 2002) of negative interrogatives have already noted that in their illocutionary force they can be similar to assertions, that is, they assert the positive statement into which the negative interrogative can be transformed. For illustration, let us consider once again the above example (3a), now given as (15a) and compare the interrogative version and the declarative version (15b). It is clear that both of them present the same proposition, equal to (15b), but it is much more prominent and stronger if worded as a question.

(15a) For example, are there not portions of some of the reading lesson books which would have no place there, if the books were compiled exclusively for the formation and the information of the female mind?

(15b) For example, there are portions of some of the reading lesson books which would have no place there, if the books were compiled exclusively for the formation and the information of the female mind.

\subsection{Statistical data}

In this section we present the statistical data for social and hard sciences in general, as well as for specific disciplines, for each of the three corpora. The identified items were counted and calculated as tokens per 10,000 words. In that way our results can be compared to the data obtained by Hyland (2002b, 2004, 2008), who used a considerably larger corpus. 
Table 1. Interrogatives in social sciences in the three corpora

\begin{tabular}{|l|c|c|}
\hline Corpus & Items found & Tokens per 10,000 words \\
\hline English (ET) & 64 & 5.1 \\
\hline Serbian (ST) & 75 & 6.0 \\
\hline English written by Serbian writers (ETS) & 71 & 5.7 \\
\hline Total: & 210 & 5.6 \\
\hline
\end{tabular}

Table 2. Interrogatives in the hard sciences in the three corpora

\begin{tabular}{|l|c|c|}
\hline Corpus & Items found & Tokens per 10,000 words \\
\hline English (ET) & 4 & 0.04 \\
\hline Serbian (ST) & 6 & 0.06 \\
\hline English written by Serbian writers (ETS) & 5 & 0.05 \\
\hline Total: & 15 & 0.05 \\
\hline
\end{tabular}

Table 3. Interrogatives in specific disciplines in the three corpora

\begin{tabular}{|l|c|c|c|}
\hline $\begin{array}{l}\text { Academic } \\
\text { discipline }\end{array}$ & $\begin{array}{c}\text { Items found } \\
\text { in English corpus }\end{array}$ & $\begin{array}{c}\text { Items found } \\
\text { in Serbian corpus }\end{array}$ & $\begin{array}{c}\text { Items found } \\
\text { in English corpus written } \\
\text { by Serbian writers }\end{array}$ \\
\hline Sociology & 26 & 30 & 29 \\
\hline Philosophy & 34 & 38 & 37 \\
\hline Psychology & 4 & 7 & 2 \\
\hline Chemistry & 1 & 3 & 1 \\
\hline Geology & 1 & 2 & 2 \\
\hline Ecology & 2 & 1 & 76 \\
\hline Total & 68 & 81 & 2 \\
\hline
\end{tabular}

\section{Discussion}

On the basis of the examined statistical data, several observations and comments can be made.

First, as we can see, our statistics for English (although on a much smaller and less diverse corpus) are in line with Hyland's findings (2002a, 2002b, 2004, 2008) both regarding the general frequency count and discipline-specific frequency count.

Regarding Serbian, for which there have been no similar previous studies, the data for the Serbian corpus show a (slightly) higher general frequency count than the one for English. Also, our findings indicate that Serbian academics tend to use more interrogatives than their English colleagues both when writing in their mother tongue and when writing in English for international readership. The use of interrogatives in the ETS corpus, somewhat higher than in ET, can be interpreted as the result of a transfer, where Serbian writers transfer some of their culture-specific writing features from Serbian into English.

As for the discipline-specific count, it can be noticed that as far as hard sciences are concerned, there is not much difference - interrogatives are extremely 
rare, in all three corpora, and for all three disciplines. On the other hand, in soft sciences there are generally more interrogatives and Serbian academics tend to use more interrogatives than their English colleagues.

Looking at social sciences in particular, the data in all three corpora show that philosophy writers in both languages are the most prolific users of interrogatives (regarding both frequency and variety). Comparing sociology and psychology articles, there are more interrogatives in academic articles of a theoretical type than in those which present the author's experimental research. Articles in experimental psychology do not contain many interrogatives, which can be easily explained by the fact that experimental research articles in soft sciences are closer both in methodology and style to the articles in hard sciences. However, it should be remarked that in selecting the journals for our corpus, though we have tried to include the journals of similar scientific category and orientation, we were unable to make an ideally uniform corpus for all three subtypes. This is especially true for Serbian journals, which are of a relatively general nature, since sociology and psychology journals in particular often include both theoretical and experimental articles.

We have also noted that interrogatives as prominent features of interpersonal discourse, in soft sciences can appear in a series, which is extremely rare in hard sciences. We found such examples of multiple interrogatives in each corpus:

(16a) Might we not be obliged then - concretely, but differently each time - to resist withholding any determinate utterance (be it imperative or indicative) from the play of the address-event? Might we not be obliged precisely to participate 'actively' in the movement of the address, to speaking/or listen, thereby allowing determinate utterances (categorical imperatives included) to stand forth in their own precarious, existential singularity, exposing their own constitutive 'default'? Is it not the exposure of this default (i.e. the presentation - withdrawal of the imperative) the exposure of the inadequacy which is essential to every formulation, including Nancy's own - which solicits the other's reciprocal rejoinder? And is it not the possibility of such a rejoinder the very possibility of a continued accomplishment of interruption, of praxis, of 'that echo which is not a repetition'? (ET8/s, p. 46)

(16b) Istovremeno, da li to znači da da je realna i bojazan za blagostanje država i pojedinaca, u slučaju osporavanja obaveze države da se stara o životnom standardu i socijalnoj sigurnosti društva? Ili: da li se potreba za blagostanjem koje obezbeđuje država smanjila u uslovima uvećanja društvenog i individualnog bogatstva? Da li društvena svest (i savest) podržava opstanak države blagostanja, odnosno da li njene ciljeve i dalje smatra legitimnim? Konačno, da li je država blagostanja u potpunosti prevaziđena, do te mere da bi njene modifikacije i prilagođavanja novim socijalnim uslovima zahtevale suštinski nove kvalitete u odnosu države prema stanovništvu, da se više ne bi mogla označiti čak ni izmenjenom državom blagostanja? (ST17/s, p. 221) 
(16c) The time has come to ask ourselves about the fate of such popular projects, created at the end of the sixties of our century, concerning the convergence of ideas and systems in the development of contemporary mankind. How utopian were those projects? What road was taken today? What roads are to be taken in the immediate future? To what extent will be road taken by different nations determine their historical beings as well as the assumptions of the socio economic life in these parts of the world? Where are the limits to peculiarities? Where the fields of necessary acceptance of certain universal requirements start from? (ETS8/s, p. 211)

\section{Conclusion}

The research of the three corpora of academic articles written by English and Serbian academics in both languages has proved our assumption that interrogatives in academic articles are not a commonly used form; on the contrary, they are rarely used in both English and Serbian academic writing cultures, but are more frequent in some soft sciences than in hard sciences. Serbian academics tend to use them a bit more than English academics, both when writing in Serbian, but also when writing in English as well, which can be interpreted as a kind of rhetoric transfer, i.e. as a writing habit coming from writing in the mother tongue and transferring into writing in a foreign language.

From the pragmatic and discourse-functional point of view, interrogatives in academic writing are viewed as indirect speech acts, exhibiting a range of pragmatic functions and their subtypes (presenting the writer's purpose, involving the reader in the discussion, reinforcing the argument by inviting the reader to agree, etc.). It can also be concluded that the same types of pragmatic functions apply to academic articles written both by English and Serbian writers.

The analysis of the use of interrogatives in academic writing has shown that the understanding of this powerful rhetoric device should be incorporated in academic writing courses, where they should be primarily treated as part of interpersonal strategies, i.e. the means for building the writer-reader communication. However, it should always be borne in mind that practical teaching materials and instructions should be accompanied with specifications and details based on corpus pragmatic research.

\section{Acknowledgements}

This research was supported by the project 178014 granted by the Ministry of Education and Science of Serbia. 


\section{References}

Ädel, Annelie (2006) Metadiscourse in L1 nad L2 English. London: John Benjamins.

Austin, John (1962) How to do Things with Words, Oxford: OUP.

Bach, Kent (1998) 'Speech acts'. In: Craig, Edward (ed.) Encyclopedia of Philosophy. London: Routledge, 81-87. Accessed in May 2009 at http://online.sfsu.edu/ kbach/spchacts.html.

Biber, Douglas, Stig Johansson, Geoffrey Leech, Susan Conrad and Edward Finegan (1999) Longman Grammar of Spoken and Written English. London: Longman.

Blagojević, Savka (2004) 'Cross-cultural Differences in Academic Writing'. In: Conference Proceedings 'Culture Encounters', Novi Sad: Faculty of Philosophy, 91-99.

Blagojević, Savka (2007) 'The Use of Metadiscourse in Research Articles Written by English and Serbian Academics'. In: Language for Specific Purposes - Conference Proceedings, Podgorica: Institut za strane jezike, 17-23.

Blagojević, Savka (2008) Metadiskurs u akademskom diskursu. Niš: Filozofski fakultet.

Booth, W.C. (1961) The Rhetoric of fiction. Chicago: University of Chicago Press.

Carter, Ronald and Michael McCarthy (2006) Cambridge Grammar of English: A Comprehensive Guide to Spoken and Written English Grammar and Usage. Cambridge: CUP.

Chamonikolasová, Jana (2005) 'Comparing the structures of texts written in English and Czech'. In: Slovak Studies in English I (Conference Proceedings), Bratislava: Univerzita Komenského, $77-84$.

Chang, Yu-Ying and John Swales (1999) 'Informal elements in English academic writing: threats or opportunities for advanced non-native speakers'. In: Candlin, Christopher and Ken Hyland (eds.) Writing: Texts, Processes and Practices, London: Longman, 145-167.

Clyne, Michael (1987) 'Cultural differences in the organization of academic texts: English and German.' Journal of Pragmatics 11, 211-247.

Clyne, Michael (1988) 'Community languages and language policy.' In: Jupp, James (ed.) The Australian People. Angus and Robertson, 893-898.

Connor, Ulla (1996) Contrastive Rhetoric: Cross-cultural Aspects of Second-language Writing. Cambridge: CUP.

Crismore, Avon and Rodney Farnswarth (1990) 'Metadiscourse in Popular and Professional Science Discourse'. In: Nash, Walter (ed.) The Writing Scolar: Studies in the Language and Conventions of Academic Discourse, Newbury Park, CA: Sage, 118-136.

Crismore, Avon, Raija Markkanen and Margaret S. Steffensen (1990) 'Metadiscourse in Persuasive Writing: A Study of Texts Written by American and Finnish University Students'. Written Communication 10 (1), 39-69.

Čmejrková, Světla (1996) 'Academic Writing in Czech and English'. In: Ventola, Eija and Anna Mauranen (eds.) Academic Writing: Introduction and Textual Issues, Amsterdam and Philadelphia: John Benjamins, 137-145.

Čmejrková, Světla (2007) 'Intercultural Dialogue and Academic Discourse'. In: Grein, Marion and Edda Weigand (eds.) Dialogue and Culture, Amsterdam and Philadelphia: John Benjamins, 73-94.

Dontcheva-Navratilova, Olga (2008) 'Interaction in Academic discourse: communicative strategies for the expression of stance'. In: Tomášková, Renáta, Sirma Wilamová and Christopher Hopkinson (eds.) Ends and Means in Language: Communication and Textual Strategies in Mass Media, Commercial and Academic Discourse. Proceedings from a Conference. Ostrava: Universitas Ostraviensis, 14-18.

Frank, Jane (1990) 'You call that a rhetorical question? : Forms and functions of rhetorical questions in conversation'. Journal of Pragmatics 14 (5), 723-738.

Han, Chung-hye (2002) 'Interpreting interrogatives as rhetorical questions'. Lingua 112 (3), 201229.

Heritage, John (2002) 'The limits of questioning: negative interrogatives and hostile question content'. Journal of Pragmatics 34 (10-11), 1427-1446. 
Huddleston, Rodney and Geoffrey Pullum (2002) The Cambridge Grammar of the English Language. Cambridge: CUP.

Hyland, Ken (2001) 'Bringing in the Reader: Addressee Features in Academic Articles'. Written Communication 18 (4), 549-574.

Hyland, Ken (2002a) 'What do they mean? Questions in academic writing'. Text-Interdisciplinary Journal for the Study of Discourse 22 (4), 529-557.

Hyland, Ken (2002b) 'Directives: Argument and Engagement in Academic Writing'. Applied Linguistics 23 (2), 215-239.

Hyland Ken (2004) 'Patterns of engagement: dialogue features and L2 undergraduate writing'. In: Ravelli, Louise and Robert Ellis (eds.) Analyzing Academic Writing: Contextualized Frameworks. London: Continuum, 5-23.

Hyland, Ken (2005a) Metadiscourse: exploring interaction in writing. London: Continuum International Publishing Group.

Hyland, Ken (2005b) 'Stance and engagement: a model of interaction in academic discourse'. Discourse Studies 7 (2), 173-192.

Hyland, Ken (2008) 'Persuasion, Interaction and the Construction of Knowledge: Representing Self and Others in Research Writing'. International Journal of English Studies 8 (2), 1-23.

'Hyper grammar, writing center'. Accessed on July $10^{\text {th }}, 2010$ at http://www.writingcentre.uottawa. ca/hypergrammar/sntpurps.html

Levinson, Steven (1983) Pragmatics. Cambridge: CUP.

Mauranen, Anna (1993) Cultural Differences in Academic Rhetoric: A text-linguistic study. Frankfurt am Main: Petr Lang.

Mur-Dueñas, Pilar (2010) 'Attitude markers in business management research articles: A crosscultural corpus-driven approach'. International Journal of Applied Linguistics 19, 50-72.

Mwansoko H. J. M. (2003) 'Swahili in Academic Writing'. Nordic Journal of African Studies 12 (3), 265-276.

Nash, W. (1992) An Uncommon Tongue. London and New York: Routledge.

Povolná, Renata (2010) 'Can non-native speakers of English use contrastive discourse markers correctly when writing academic texts?' In: Malá, Markéta and Pavlina Šaldová (eds) ... For Thy Speech Bewrayeth Thee. A Festschrift for Libuše Dušková. Praha: Univerzita Karlova v Praze, 209-231.

Sadock, Jerold (1995) 'Towards a Typology of Speech Acts'. In: Tsohatzidis, Savas (ed.) Foundations of Speech Act Theory, London: Routledge, 393-406.

Sadock, Jerold (2004) 'Speech Acts'. In: Horn, Laurence and Gregory Ward (eds.) Handbook of Pragmatics, Oxford: Blackwell Publishing, 53-73.

Searle, John (1969) Speech Acts: An Essay in the Philosophy of Language. Cambridge: CUP.

'Study skills: Rhetorical questions, Warwick: Centre for Lifelong Learning'. Accessed on July $10^{\text {th }}$ 2010 at: http:/www2.warwick.ac.uk/study/cll/othercourses/itt/resource_bank/studyskills/study/ readingskills/efficientreading/rhetoricalquestions/

Stašková, Jaroslava (2004) 'Options of identity: Authorial presence in research articles abstracts'. In: Slovak Studies in English 1. Bratislava: Univerzita Komenského, 201-207.

Vande Kopple, William J. (1981) 'Experiments on the Readability of Natural Expository Paragraphs with Identical or Related Sentence Topics' microform] http://www.eric.ed.gov/contentdelivery/servlet/ERICServlet?accno=ED209631

Vande Kopple, William J. (1985) 'Some exploratory discourse on metadiscourse'. College Composition and Communication 36, 82-93.

Webber, Pauline (1994) 'The functions of questions in different medical journal genres'. English for Special Purposes 13 (3), 257-268.

Williams, J.M. (1985) Style: Ten lessons in clarity and grace. Glenview. IL. Scott, Foresman. 


\section{Appendix}

The texts were taken from the following publications:

Social sciences:

(1) Texts in English by native English writers (ETs texts)

The British Journal of Sociology, London School of Economics and Political Science, editions from $2000-2003$.

Culture \& Psychology, Sage publications, editions from 1997 - 2002.

Philosophy and Social Criticism, Sage Publications, editions from 2000 - 2005.

(2) Texts written in English by native Serbian writers (ETSs texts)

Facta Universitatis, Series Philosophy, Sociology and Psychology, University of Niš, editions from $2003-2009$.

The Sociology of Religion in the Former Yugoslav Republics, Yugoslav Society for the Scientific Study of Religion, Niš, editions from $2004-2006$.

Sociologija, Journal of Sociology, Social Psychology and Social Anthropology, Yugoslav Sociological Association, Belgrade, editions from 1997 - 2001.

(3) Texts written in Serbian by Serbian writers (STs texts)

Teme, časopis za društvene nauke, [Topics, journal for social sciences], University of Niš, editions from $2003-2008$.

Sociološki pregled, Sociološko društvo Srbije, [Sociological Review, published by Sociological Society of Serbia], Belgrade, editions from $1998-2004$

Psihologija, Društvo psihologa Srbije, [Psychology, published by Psychology Association of Serbia], Belgrade, editions from 1999 - 2007.

Hard sciences:

(1) Texts in English by native English writers (ETh texts)

Analitical chemistry, American Chemical Society, Washington, editions from 1999 - 2005.

European Coal Geology and Technology, Geological Sociaty Special Publication, London, editions from 1998-2003.

Enviromental Pollution, Elsevier Science, Great Britain, editions from 2001 - 2007

(2) Texts written in English by native Serbian writers (ETSh texts)

Journal of the Serbian Chemical Society, Belgrade, editions from 1998 - 2003

Facta Universitatis, Series Physics, Chemistry and Technology, University of Niš, editions from $2001-2006$.

Risk Technological Systems and the Enviroment, Proceedings of RISK'97, Fakultet zaštite na radu, [Faculty of Occupational Safety], Niš, 1997.

(3) Texts written in Serbian by Serbian writers (STh texts)

Hemijski pregled, Srpsko hemijsko društvo, [Chemical Review, published by Serbian Chemistry Society] Belgrade, editions from 1998-2006.

Geološki anali balkanskog društva, [Geological Annals of Balcan Association], Institut za MKPG, editions from 1999 - 2004.

Ecologica, Naučno-stručno društvo za zaštitu životne sredine Srbije, editions from 2001 - 2008. 
Savka Blagojević is an associate professor in applied linguistics at the Faculty of Philosophy, Niš, Serbia, teaches English and Academic writing. She is the author of the monograph Metadiscourse in Academic Discourse (in Serbian) and the coursebook English for Philosophy Students, as well as several dozen articles on contrastive rhetoric, discourse analysis, ESP, and methodology of EFL and ESP, which are the areas of her research and scientific interests.

Address: Prof. Savka Blagojević, English Department, Faculty of Philosophy, Ćirila i Metodija 2, 18000 Niš, Serbia. [email: savkab@filfak.ni.ac.rs]

BiLJANA Mišıć ILIĆ is a full professor of the English language and linguistics at the English Department, Faculty of Philosophy, University of Niš, Serbia. She wrote two syntax coursebooks for EFL students, two monographs covering topics in syntax, pragmatics, semantics and discourse, and co-edited seven books of proceedings from international conferences organized by the Faculty of Philosophy in Niš, as well as a collection of articles Identity Issues: Literary and Linguistic Landscapes for Cambridge Scholar Publishing.

Address: Prof. Biljana Mišić Ilić, English Department, Faculty of Philosophy, Ćirila i Metodija 2, 18000 Niš, Serbia. [email: bmisicilic@gmail.com] 
